\title{
電子線トモグラフィ法の材料開発への応用 一投影像は三次元情報を正確に反映しているか?-
}

$\begin{array}{lll}\text { 伊野家 浩 } & \text { 司* 金子 賢 治** } \\ \text { 堀 田 善 治*** }\end{array}$

\section{1. は じめに}

材料開発において, 巨視的な機械的特性や電気的特性を知 るうえで走査型電子顕微鏡 (Scanning Electron Microscope : SEM) や透過型電子顕微鏡 (Transmission Electron Microscope : TEM) 等を用いた微細構造観察や組成分析が不可欠 である，例えばデバイス等の高性能化, あるいは新しい高機 能材料, 新デバイスの創出は, 原子レベルの微細構造を制御 することによって達成することが可能となり, 結晶粒径や析 出物の分布, サイズを評価することにより, 材料の高強度化 や高勒性化のメカニズムが明らかとなる. 無機材料や金属材 料では, 結晶中の欠陷や添加物等の空間分布, 元素の結合状 態や種類によって特性が決定される.これらの機能, 特性な ぞを含めた微細構造の評価, 新現象の解明には, ナノスケー ルの二次元, 三次元観察と高精度な元素分析が必要となる.

一般的には特定の部位，方位などを含む目的に応じた試料作 製を行い, TEM を用いてナノスケールの微細構造評価を行 った上で, マクロスケールの材料特性の評価と組み合わせて 検討する. 近年, 更なる材料特性の向上を図るため, 高い空 間分解能や高いエネルギー分解能での解析が求められている.

TEM による組織観察の結果得られる二次元情報は三次元 構造の投影であるが, 現実には試料が有する大部分の三次元 情報が破棄されている．単純な系の合金や半導体デバイスの 場合であれば，真の三次元情報が得られる場合もある。しか し, ほとんどの実用材料が複雑な形状や構造を有し, TEM の二次元投影像からだけでは真の三次元情報を得る事は不可 能である. 特にその複雑な構造や形状により物性が大きく左
右される場合, 二次元の投影像からは “もっともらしい”情 報も得られるが，誤った解釈をしてしまう可能性が大であ る.このような事態を避けるべく，一枚の投影像から全てを 判断するのではなく, 可能な限り多くの投影像から三次元情 報を得る必要がある。

三次元情報を得る手法として, 三次元アトムプローブ法 (Three-Dimensional Atomic Probe : 3DAP)(1)やX 線コン ピュータ断層撮影法 (X-ray Computed Tomography : X 線$\mathrm{CT})^{(2)}$, 陽電子放射断層撮影(Positron Emission Tomography : PET)(3)などがある. 3DAP は分解能が原子レベルに 到達しているものの三次元観察の可能な体積が限定され, 試 料形状に制約がある。 また X 線一CT は比較的大きな寸法の 情報が得られるが， $\mathrm{X}$ 線を使用するため $1 \mu \mathrm{m}$ 程度の空間分 解能しか得られていない等，それぞれの手法においてメリッ

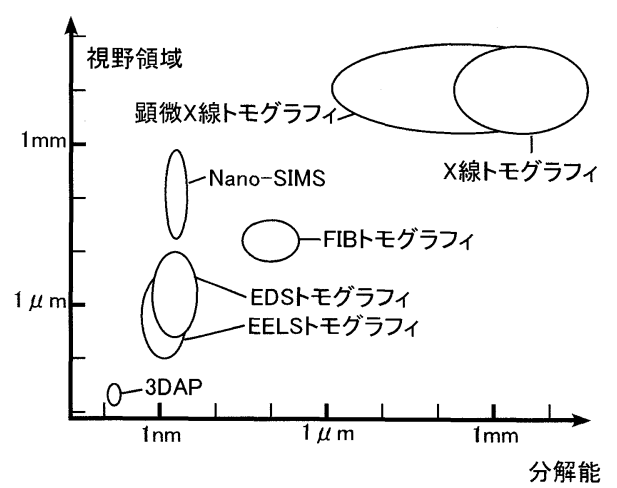

図 1 それぞれの手法による視野領域と分解能の関係 (文献 4 より抜粋).

* 日本エフイー・アイ株式会社アプリケーションラボラトリ主任技術員 (テ108-0075 東京都港区港南 2-13-34 NSS-II ビル 1F)

** 九州大学助教授; 大学院工学研究院材料工学部門

*** 九州大学教授; 大学院工学研究院材料工学部門

Application of Electron Tomography for Material Science-Can you Estimate Three-Dimensional Object from Two-Dimensional Projections?-; Koji Inoke*, Kenji Kaneko**, Zenji Horita*** (*FEI Company Japan, Ltd. Application Laboratory, Tokyo. ${ }^{* *, * * * K y u s h u}$ University, Department of Material Science and Engineering, Fukuoka)

Keywords: electron tomography, projection, reconstruction, back projection, TEM; Transmission Electron Microscope, HAADF-STEM; High Angle Annular Dark Field-Scanning Transmission Electron Microscope 2006年 2 月 6 日受理 
トやデメリットがある(図 1) ${ }^{(4)}$.

近年，TEM とトモグラフを組み合わせた電子線トモグラ フィ法 (Electron Tomography：ETまたはThree-Dimensional Electron Tomography : 3D-ET)の結晶性材料への応 用が報告され始めてきている(5)(6). 3D-ET 法は試料の同一 視野領域の投影像を傾斜しながら数十枚から百枚程度撮影 し，これらの TEM 投影像をコンピュータ処理し，再構築を 行うことにより三次元の情報を得る方法である. 最近では再 構築像はの空間分解能が数 $\mathrm{nm}$ 前後に到達し, 実用材料の開 発に新たな知見をもたらす重要な手法の一つとして期待され ている.

\section{2. トモグラフィ}

\section{(1) 背 景}

トモグラフィとは，本来様々な方位から X 線を照射し， その透過量を測定し，コンピュータにより横断面像をブラウ ン管に描き出す方法である。その歴史は古く，1963年の $\operatorname{Cormack}^{(7)}$ によるX 線-CT の理論的考察と数学的解析に関 する論文(ノーベル生理学・医学賞を1979年に受賞した)に 遡る.この理論的考察と数学的解析は，1917年に Radonに よって既に示されており(ラドン変換) ${ }^{(8)}$ ，この原理に基づい たコンピュータ断層撮影器 (Computed Tomography : CT) がイギリスEMI 社の Hounsfieldによって1972年に開発さ れている ${ }^{(9)}$. 当初 CT は体の横断面像の撮影に用いられてい たが，1990年代になるとX線を体の周りに回転させること で三次元情報の取得が可能になり (helical CT) ${ }^{(10)}$ ，撮影した 領域で任意な断面を得て，立体画像を表示することが可能と なった．最近では，心蔵や腸管の動きの鮮明な画像をも観察 できるようになってきている，また，工業分野においては高 出力の X 線を利用した非破壊検査などに利用されている(11).

TEM とトモグラフィの組み合わせは1968年の DeRosier と Klug ${ }^{(12)}$ による T4 ファージ鞭毛の螺旋構造の発表に始ま る. 当時は電子線による試料損傷の度合が大きく, またコン ピュータの処理速度が遅く, データ処理容量が少ない等の問 題があり，三次元情報を得ることはほぼ不可能であった。最 近では，厚い領域を観察するための高加速電圧化, 非弾性散 乱の除去のためのエネルギーフィルタの応用, 液体ヘリウム 温度での観察(クライオトモグラフィ)による電子線損傷の軽 減(13)等，様々な工夫が図られている。あた $3 \mathrm{D}-\mathrm{ET}$ 法が普 及し始めた理由に, TEM 機能の自動化 ${ }^{(14)}$, 周辺機器の一 体化，ならびに自動化に伴うレンズ系，試料ステージ，焦 点, 試料高さ, 非点補正, 試料傾斜等のコンピュータ制御が 進んできていることが挙げられる. また, 観察時にデジタル 画像が取得可能な電荷結合素子 (Charge Coupled Device : CCD) カメラが普及したことによる. CCD カメラはそれぞ れの連続傾斜像の取り込みの際に生じる回転軸のずれの測定 に欠かせなく，ずれを補正することで共通視野部の多い画像 取得が可能になる. このような技術の進歩の結果, 画像取得 や再構築に必要な時間が大幅に短縮可能となった.

（2）原 理

3D-ET 法は三次元物体の一断面 (二次元) 投影像を “ラド
ン定理”に従って一次元の線にフーリエ変換するという数学 的な考えに基づいている(8). 実際には試料を TEM 内で数度 ずつ傾斜しながら投影像を得て, それらのフーリ工変換を行 い, 多数の位置断面投影像を得る. こうして得られた多数の 断面像から, 位相のずれや輪郭を強調し, フーリ工逆変換す ることで本来の三次元物体の情報を得る.

TEM への応用にめたっては，データを取得する部分と得 られたデータを再構築する部分とに分けられる. 前者は主に TEMのハードウェアの進歩によってより短時間に, 後者は ソフトウェアの開発とコンピュータハードウェアの発達によ ってより簡便になっている. 特に対象領域の 3 次元再構成 を行うソフトウェア（例えば, 米コロラド大の Boulder Laboratory から学術目的で使用可能な IMOD, その他電子 顕微鏡メーカーから販売されているソフトウェアなど）と再 構成したデータを可視化する市販ソフトウェアを用いること により 3 次元可視化が可能となる.

\section{（3） 3D-ET 法}

3D-ET 法は基本的に X 線-CT や磁気共鳴画像法 (Magnetic Resonance Imaging : MRI)などによる断層撮影と同じ 原理である. X 線-CT 等の場合, 検出器が体を中心に旋回 するのに対して，3D-ET 法では電子線に対して試料が傾斜 する手法を用いている. 試料を高角度 $\left(\sim 80^{\circ}\right)$ に傾斜し, 連 続的に投影像を取得し, 一連の連続傾斜像からその切片の三 次元情報を再構築する. 試料膜厚は電子線が透過できるよう に〜数百 $\mathrm{nm}$ 程度である.

\section{(a) 連続傾斜像の取得 (図 2(a))}

試料をTEM 内で試料を傾斜しながら連続的に TEM 像 (投影像)を撮影する. 各投影像には試料厚さ方向の情報が重 なるため, 通常正確な三次元の構造の把握は困難である. たTEMの試料ステージの最大傾斜角による制限から通常は 試料の全方位の投影像を得ることは出来ない.

(b) 画像のアライメント(図 $2(\mathrm{~b})$ )

コンピュータ上でこれらの投影像の位置補正や明るさ, 倍 率の補正を行い, “ラドン定理”に従ってフーリエ変換する.

(c) フーリエ空間での合成 (図 $2(\mathrm{c})$ )

このフーリエ変換された全投影データをその投影のビーム に沿って，傾斜角の情報をもとに空間に当てはめ，その重ね 合わせを行い, 三次元化する.

(d) フーリエ空間から実空間への変換(図 2(d))

3 次元化されたデータの逆フーリエ変換により, 実空間で の三次元像を再構成する. 三次元表示ソフトウェア等を用い て, 三次元構造の可視化や分布, 寸法など様々な解析を行う.

\section{3D-ET}

\section{（1）使用する信号}

TEM による薄片試料の観察では, 傾斜時に試料膜厚が増 加するため, 非弾性散乱電子が増加し, 電子レンズの色収差 (像のボケ)が発生し, 像質が低下してしまう。これは試料を 透過した電子に, エネルギーを失わない弾性散乱電子(ゼロ ロス)と, プラズモンや内殼電子を励起することによりエネ ルギーを失う非弾性散乱電子が混在することに起因する。こ 
(a) 物体の投影像の取得

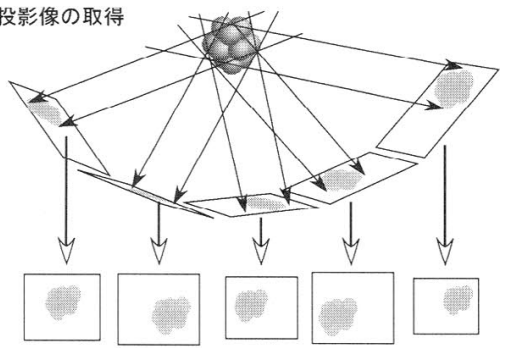

(b) 傾斜軸に沿つた画像位置アライメント

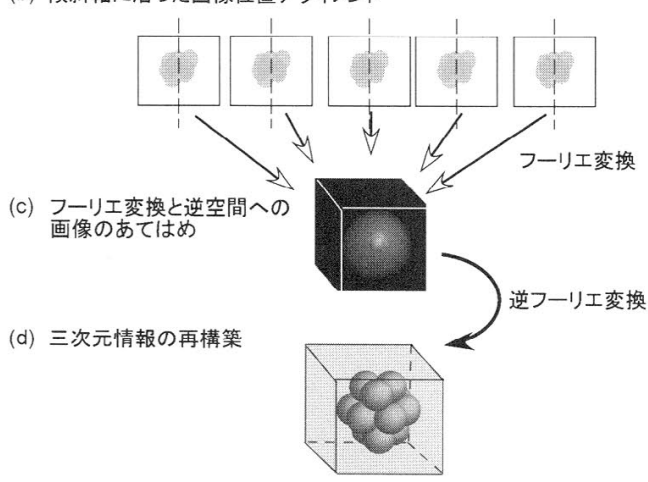

図 2 トモグラフィの再構築の流れ.

の像のボケはエネルギーフィルタを使用し, 非弾性散乱電子 を除去することにより改善することが可能であり, データ取 得時や再構築時の位置あわせ精度の向上，また投影像の分解 能向上に役立つ.

試料が厚い場合, 入射電子の多くは試料に吸収され, 透過 する電子の数が減少し暗く映る.このようにして生じるコン トラストを吸収・厚みコントラストという。再構築を正確に 行うためには，この吸収・厚みとコントラストの相関が一義 的である必要がある. 生物試料や高分子材料の様な非晶質材 料の場合, 投影像のコントラストは吸収・厚久コントラスト の考え方で解釈できる。例えば，透過波の見かけ上の吸収は， 危みとしたとき

$$
\frac{N_{0} \sigma_{a t o m}}{M} \rho t
$$

ここで， $N_{0}$ はアボガドロ数， $M$ は分子量， $\sigma$ は微分散乱 断面積を対物絞りの大きさから高角側へ積分したものであり, $\rho$ は密度である。このため, 試料膜厚が既知であれば，傾斜 角と試料厚久の関係から密度や分子量などの三次元情報を得 ることが可能となるのである.

しかし 3D-ET は結晶性材料の解析には適さない. その理 由は, 二次元傾斜像の取得時に, 非晶質材料とは異なり, 傾 斜角度によっては電子回折現象が生じ回折コントラストが発 生するからである。この回折コントラストは，吸収・厚みコ ントラストとは異なり, 密度や分子量の変化上は無関係であ る。この結果, 再構築像に偽像が発生してしまう。この回折 コントラストの影響を抑えるため, 最近では走査型透過電子 顕㣲鏡 (Scanning-TEM : STEM) と環状検出器を用いて高 角散乱した電子を用いて結像する高角環状暗視野 (High-Angle Annular Dark-Field : HAADF) 法を 3D-ET と組み合孔 せるSTEM-HAADFトモグラフィ法を用いての三次元観察 が試みられている(15).
この STEM-HAADF 法を用いて得られた像のコントラス 卜は原子番号の二乗に比例し，試料厚さやデフォーカス量に よって像コントラストが反転しない, また, 分解能も TEM の高分解能像と比較しても原理的に優位とされており，原子 番号の大小に応じてコントラストが異なるため(16)，三次元 の組成分布像を得ることも可能である.

\section{（2）電子線損傷の低減}

3D-ET 法を行うためには同一の視野を様々な方位から投 影する必要がある。このため，同一領域が長時間にわたり電 子線の照射を受ける。特に電子線に対し弱い試料を対象とす る場合は，照射の影響を避けるため，様々な対策を講じる必 要がある，例えば，試料を液体へリウム温度まで冷却するク ライオトモグラフィ法(13)(17)，意図的に観察する視野とは異 なる領域を位置合わせに用いる低電子線照射量モード 法(18)(19)などがあげられる。

\section{(3) 再構築手法}

3D-ET 法には，二次元の連続傾斜像から三次元情報を再 構成する再構築処理の課程が必要である。これまでに，いく つかの再構築処理法が提案されており，ここでは代表的な例 を挙げる。

(a) バックプロジェクション法(17)(20)

トモグラフィの再構築法として広く採用されている方法で ある. 基本的には様々な傾斜角度で取得した画像を元の物体 に逆に投影する方法である。即ち電子顕微鏡内で起こってい る現象, プロシェクション(図 3), とは逆を行うため, バッ クプロジェクション(図4)と呼ばれる.

実空間の $x y$ 平面に打ける画像を $f(x, y)$ とし，電子線を $\theta^{\circ}$ で照射した時の位置 $r$ に打り投影データを $p(r, \theta)$ とす ると, $f(x, y)$ は次式で与えられる.

$$
f(x, y)=\int_{0}^{\pi} p(x \cos \theta+y \sin \theta, \theta) d \theta
$$

式 $(2)$ をそのまま適用して画像再構成を行う方法は単純逆 投影法と呼ばれる(図 5)。

しかし，単純逆投影法では周波数に応じた情報の粗密が生 じるため，情報量が均一になるように高周波を強調するフィ ルタをかける。これは，投影データに対し重畳積分(コンボ リューション）した後でバックプロジェクションを行うこと によってボケを補正する方法であり，フィルター・バック・ プロジェクション(Filtered Back Projection：FBP)と呼ば れる(図 6).

\section{(b) ART 法(21)(22)}

代数的再構成法 (Algebraic Reconstruction Technique： ART) と代数的反復法 (Simultaneous Iterative Reconstruction Technique : SIRT) は共に傾斜像と再構築された三次元 情報の投影像を比較しながら再構築を行う方法である。それ ぞれの違いは再構築する三次元情報の更新の方法にあり， ART は個々の投影後に再構築された三次元情報を補正し， SIRT は初めに全ての投影像を使用して補正するための三次 元情報を構築しこれを用いて再構築情報を更新する。どちら の手法も膨人な計算能力を要するため, バックプロシェクシ ヨン法よりも計算時間は長くなる(23). 


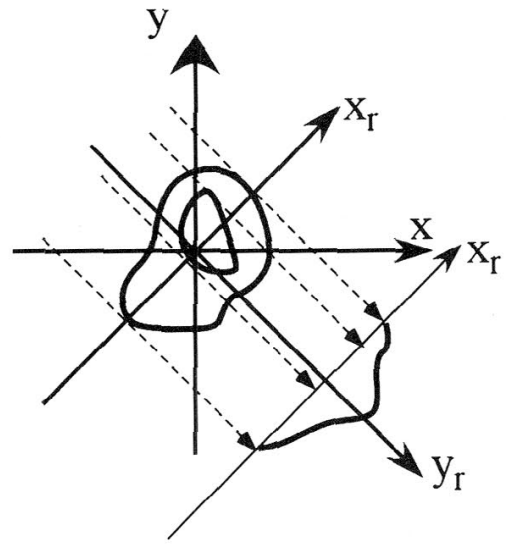

図 3 物体の投影(プロジェクション).

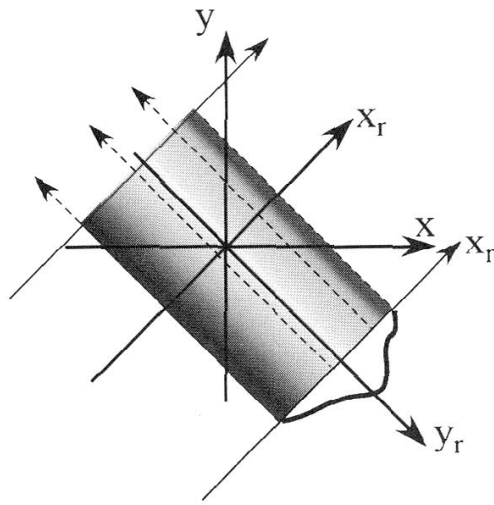

図 4 物体の逆投影(バック・プロシェ クション).

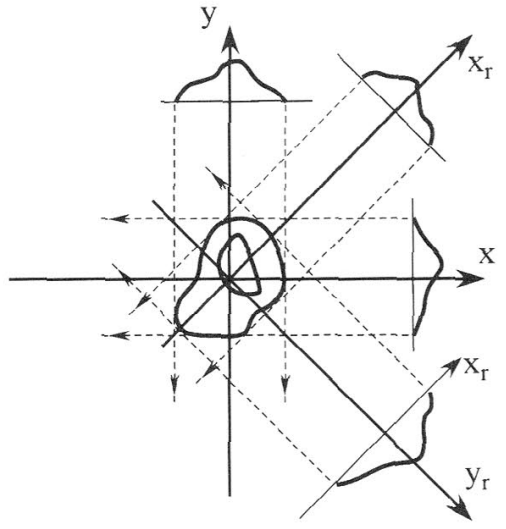

図 5 物体 $\sigma$ 再構築.

\section{(4) 試料形状による異なるアプローチ}

通常, TEM 観察には試料の薄片化 $(<100 \mathrm{~nm})$ を必要とす る。特に高分解能観察や電子エネルギー損失分光 (Electron Energy-Loss Spectroscopy：EELS)解析を行う場合, 原子 の直視や元素の化学結合状態が膜厚に敏感であるため試料の 更なる薄片化が必要となる。逆に 3D-ET の場合は膜厚方向 ( $\mathrm{z}$ 方向)の情報を得るために, ある程度の試料膜厚が必要で ある。ささらに連続傾斜像を取得する際, 試料膜厚が傾斜と共 に增加してしまうため3D-ET 法に抢いては試料膜厚上得ら れる情報のバランスを考慮する必要がある。

\section{(a) 薄片試料の場合}

薄片試料を用いる3D-ETのメリットとしては，倍率に応 じて比較的大きな視野が取れることが挙げられる。デメリッ トとしては試料を高傾斜した際に，視野が制限されてしまう ことや試料膜厚が増加してしまうことである。例えば， $0^{\circ}$ 傾 斜時に厚さ $t_{0}$ の試料は角度 $\theta^{\circ}$ 傾斜した場合には膜厚が $t=$ $t_{0} / \cos \theta$ となる. この試料傾斜角度の制約による情報の欠落 はフーリエ空間においては楔状であるが，お互いに直交する 傾斜軸に試料を傾斜させ連続傾斜像を取得することで情報欠 落の領域を角錐状に減少させることが可能となる(図 7) (24).

現在, 二軸傾斜 3D-ET 法のための試料ホルダーがメーカ 一から発表さ机情竍の欠落が少ないデータの取得が可能とな ってきているが，再構築に困難さが生じている(25)(26)。一軸 傾斜 3D-ET 法では各連続傾斜像がある一次元の傾斜軸上に 観察領域があればよいが，二軸傾斜 3D-ET 法の場合では， それぞれの傾斜軸の成す角度上傾斜軸のフーリ工空間内での 位置を精密に調整する必要がある。それぞれの傾斜軸の再構 築像を加えるアプローチや演算を繰り返すアプローチ等(27) 試みられているが，今後更なる開発が望なれている.

\section{(b) 柱状試料の場合}

(a)で述べたように薄片状のTEM試料を用いる場合, $90^{\circ}$ の傾斜を行うことは試料, 電子顕微鏡の双方において物 理的に不可能である.この問題を克服するため, 試料に集束 イオンビーム(Focused Ion Beam : FIB) 加工を施し, 径が $100 \sim 200 \mathrm{~nm}$ 程度の柱状の試料を作製し $90^{\circ}$ の傾斜を行う 3D-ET 法が提案されている、柱状であれば試料による傾斜 の制約を受けず，360 の回転が可能となり，情報欠落が低 減され，上り確かな三次元情報を得る事が可能となる(28).
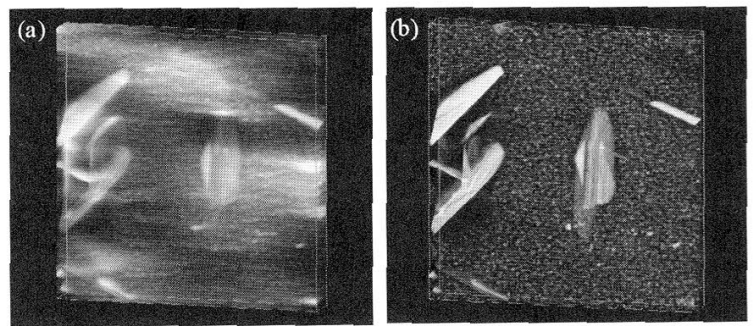

図 6 バック・プロジェクションに招けるフィルタの 効果. (a)フィルタ無し, (b)フィルタ有り. (a)

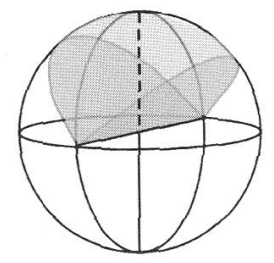

(b)

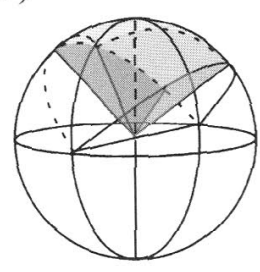

(b)二軸傾斜

$93 \%$

$84 \%$

$57 \%$
図 7 一軸傾斜 (a) 上二軸傾斜 (b)によるフーリ工空間 での情報範囲 (24).

\section{（5）その他；組成分布の三次元観察}

組成分布の三次元観察は形態の観察と共に大きな目標とな っているが, 試料傾斜するため, 試料膜厚の変化や検出器 に対するジオメトリの変化は避けられない. エネルギーフィ ルタを用いた例(29)や EDS を用いた例(4)があるがぞちらも組 成や試料の形状に大きく依存してしまう。

\section{4. 応用例}

(1) 金属系 $\mathrm{AI}-\mathrm{Ag}$ 系析出合金の適用例(30)

$\mathrm{Al}-\mathrm{Ag}$ 系の合金には面心立方構造の $\mathrm{Al}$ 母相中の $\{111\}$ 面 と平行に面を有するギニエープレストン帯 (Guinier-Preston zone：GP 帯) が発生する(31). Kelly と Nicholson ${ }^{(32)}$ は通過 
する転位によって GP 带がせん断されるというモデルを提案 している(図 8).

$\mathrm{A} 1-\mathrm{Ag}$ 系に括沙る GP 带の二次元的な変形, 円から楕円 は Nicholson と Nutting ら(31)によって既に報告されている が，これらの変形した GP 帯の三次元の形態やそのひずみに ついては未だ報告されていない。

3D-ET 法を用いることにより試料中の GP 帯への影響, 特に寸法, 分布, 形態を三次元で観察し, 強ひずみ加工 $(\mathrm{ECAP})$ 前後の $\mathrm{Al}-\mathrm{Ag}$ 合金中の $\mathrm{GP}$ 帯の形状変化の観察を 行った.

供試材は高純度 $\mathrm{Al}$ と Ag t溶解して鋳造し均質化処理

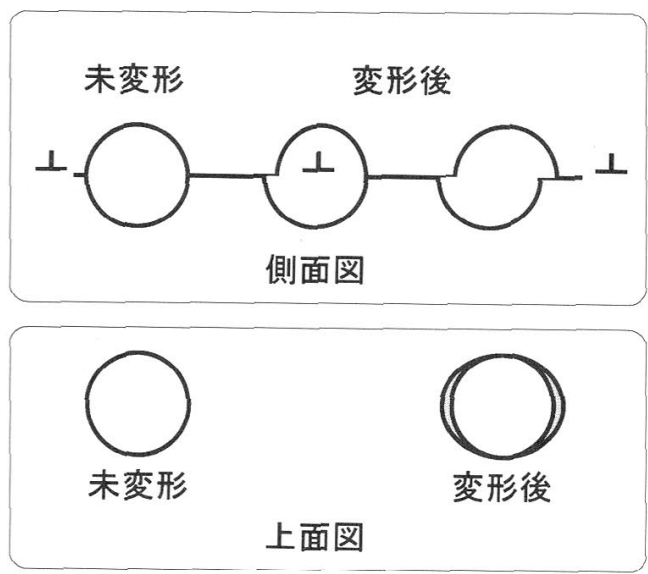

困 8 通過する転位による GP 帯のせん断モデル(32).
後, ロッド状にスウェージ加工し強ひずみ可能 (EqualChannel Angular Pressing : ECAP) 法(33)を施したものでめ る. 図 9 に示すように未変形の材料ではほぼ球形の GP 帯と $\gamma^{\prime}$ 相が観察されるが，ECAP 処理を加えた試料では(図10)楕 円体の GP 帯から構成されるせん断带の存在が観察され, 隣 接する $\gamma^{\prime} か ゙$ 転位の世ん断運動によって变形している様子が 伺える.

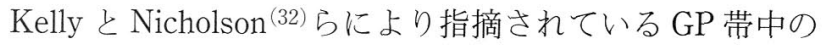
転位の存在は試料膜厚のため観察することは困難であった。

しかし，これらの GP 帯が転位によってせん断され変形は 数原子層に限られせん断帯が発生する事になる。転位によっ て GP 帯がせん断され数原子層のずれが生じるとすれば，歪 量に応しててすべり面と棈円形の析出物の長軸との成す角度が 変化すると考えられる(図11).

変形前の GP 带の体積は $(4 / 3) \pi r^{3}$ で与えれ，変形後の $\mathrm{GP}$ 帯の体積が (4/3) $\pi a^{2} b$ で与えられるとすると, $r$ と $a, b$ の間には単純に $r^{3}=a^{2} b$ が成り立つ. GP 帯の直径の平均は 5.5( $\pm 0.5 \mathrm{~nm}$ であり, 変形前後での体積は一定であり，楕 円体の短軸長軸比 $\mathrm{b}: \mathrm{a}$ が $1: 1: 3.0( \pm 0.2)$ であると判明し た。棈円体の長軸方向と〈110〉とのなす角は平均 $28.6^{\circ} \pm$ $3.17^{\circ}$ であり，このことから平均局所ひずみ量 $\gamma$ は単純に, $\approx \tan \left[90.0^{\circ}-\left(28.6^{\circ} \pm 3.18^{\circ}\right)\right], つ 屯 り \approx 1.83 \pm 0.272$ づあ と計算できる，強ひずみ加工を一回施した場合，そのひずみ 量は約 1 であることから, 局所領域 (せん断帯)では約 2 倍 に相当するひず久が発生していることが解った。
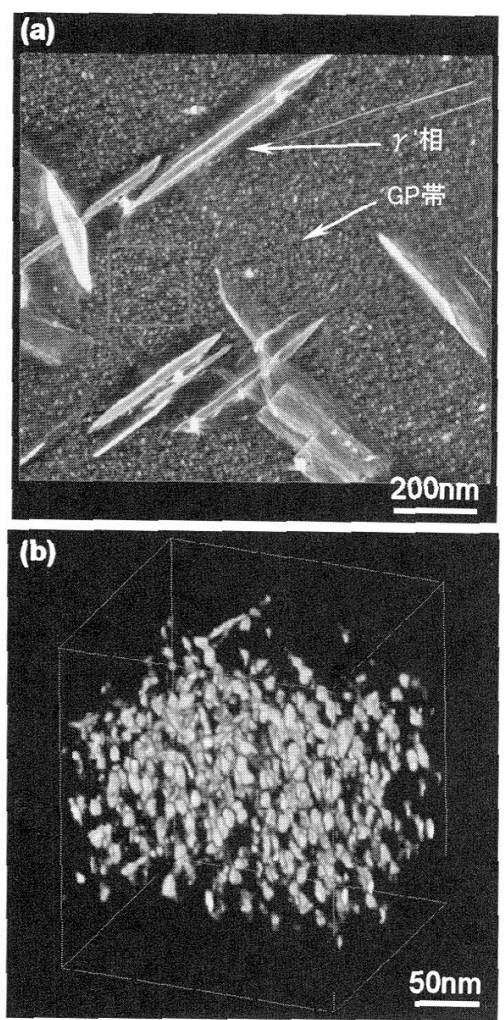

図 $9 \mathrm{~A} 1-\mathrm{Ag}$ 合金の未变形材料に 打汀る再構築像.

(a) 再構築像, (b) (a) 枠で 指定した部位の拡大.
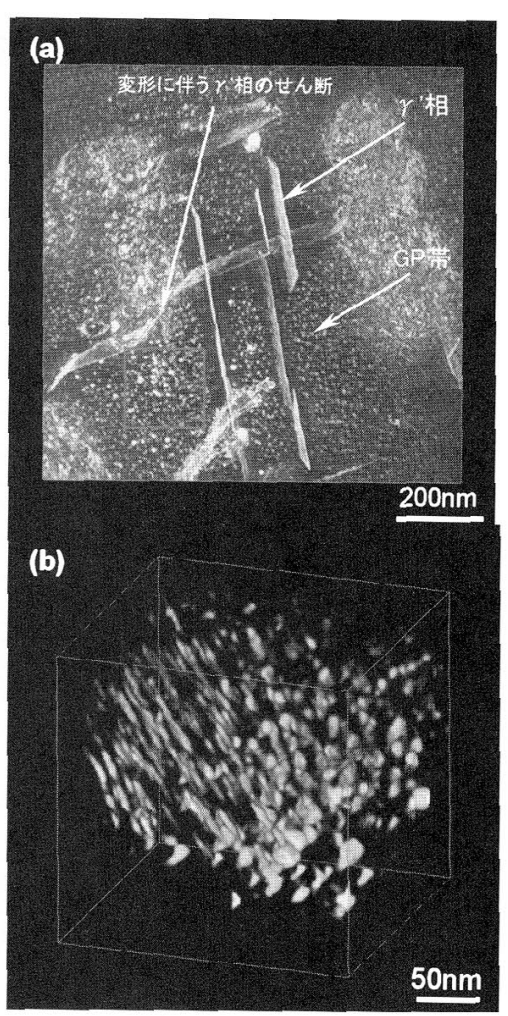

図10 ECAP 処理後 $\mathrm{Al}-\mathrm{Ag}$ 合金の 再構築像.

(a) 再構築像, (b) (a)枠で 指定した部位の桩大.

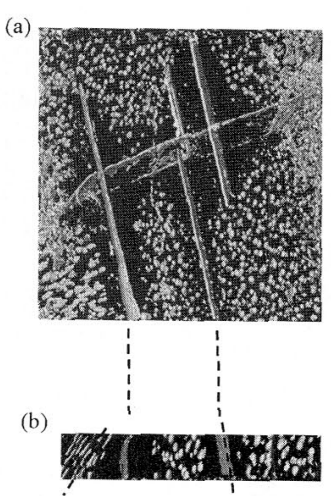

(c)

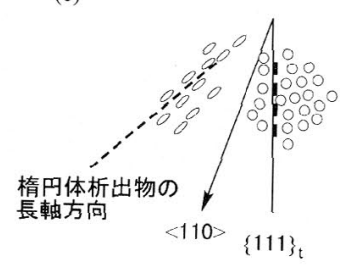

蜂卫体析出物の 長軸方向

図11 女ん断帯における楕円線の角度と方位の関 係. 


\section{(2) $\mathrm{Al}-\mathrm{Si}$ 系析出合金の適用例 (34)}

$\mathrm{Al}-\mathrm{Si}$ 二元系合金に抢ける $\mathrm{Al}$ と $\mathrm{Si}$ との固溶度は小さく， 溶体化処理した $\mathrm{Al}-5$ mass $\% \mathrm{Si}$ 合金を時効すると，板状，口 ッド状などいろいろな形状を有する Si が析出する.

$\mathrm{Si}$ 相析出物が母相中に分散していることは投影像からも 判別可能であるが，形状が針状であるのか板状であるのか， 投影像からは容易に判別がつかない．Si 相の形態は塑性加 工性に最も大きな影響を及ぼす組織的因子であるため，これ らの析出物の分布状態と形状を把握することが重要である.

供試材は高純度 $\mathrm{Al}$ と Si t溶解して鋳造し均質化处理の後, $850 \mathrm{~K}$ で $1 \mathrm{~h}$ の溶体化处理を行い $473 \mathrm{~K}, 10 \mathrm{~h}$ の時効処理を 行った.

$\mathrm{Al}$ 母相中の Si 相であるため, STEM-HAADFトモグラ フィを用いることによる析出物の三次元可視化は不可能であ り, 単純に明視野像加らの再構築を行った. 回折条件を意図 的に外す様に，試料をホルダーに乗せたことから，傾斜にお ける回折コントラストを避けることが可能となり, 偽像の影 響を避けることが可能となった例である。

図12に変形前の試料を $-60^{\circ} \sim+60^{\circ}$ の範囲にわたって, $2^{\circ}$ 刻及で撮影したときの連続傾斜像の一部(図中は $10^{\circ}$ 刻及)

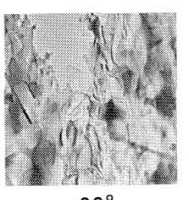

$-60^{\circ}$

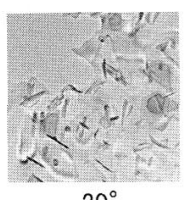

$-20^{\circ}$

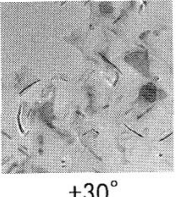

四12 Al-Si 合金について取得した連続傾斜像.
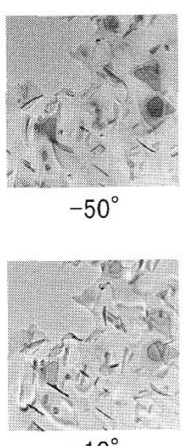

$-10^{\circ}$

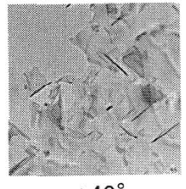

$+40^{\circ}$
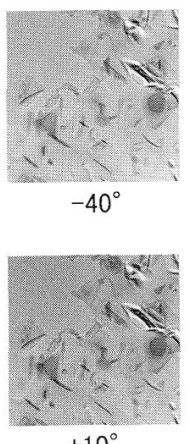

$+10^{\circ}$

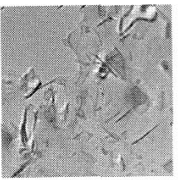

$+50$
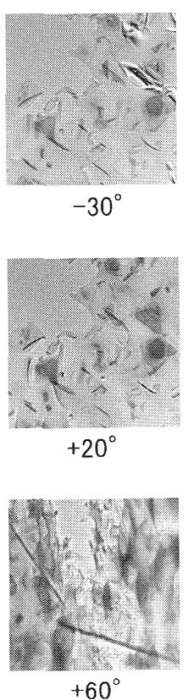

$+60^{\circ}$

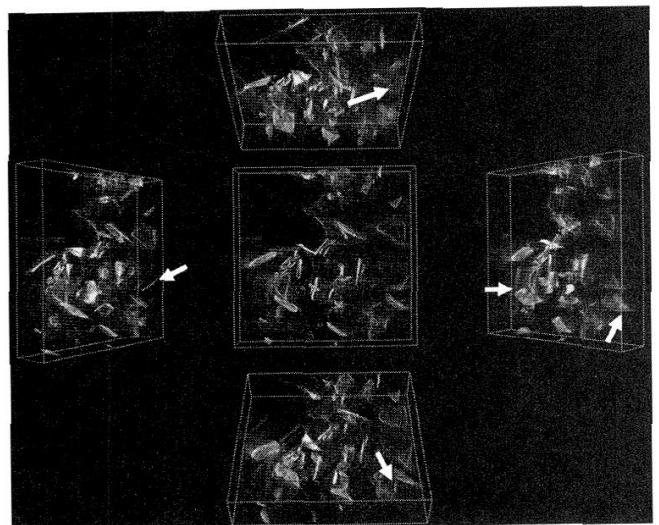

図13図12で示した Al-Si 連続傾斜像から得られた三 次元再構築像. 図中白矢印がロッド状析出物.
を示す，再構築された三次元像からは薄膜中の $\mathrm{Si}$ 相の分布 が判り，かつ板状とロッド状の Si 相を容易に判別すること が可能となった(図13).

（3）非金属系，触媒への応用例

$$
\mathrm{TiO}_{2}+\mathrm{Ag} \text { ナノ複合粒子への応用 }{ }^{(6)}
$$

噴霧熱分解法により $\mathrm{TiO}_{2}-\mathrm{Ag}$ ナノ複合粒子を合成し，銀 の分散状態やそのサイズについての 3D-ET 解析を行った。 フォトクロミズムとは光に応答して物質の色が変化する現象 のことであり, $\mathrm{Ag}$ 担持 $\mathrm{TiO}_{2}$ の場合，照射した光と同様の 色着色する事が知られている，着色する色は青から赤なで 様々であり，この特性は，藤嶋らにより発見されたものであ る(35)。これは $\mathrm{Ag}$ 粒子のプラズモン共鳴特性と $\mathrm{TiO}_{2}$ の半導 体特性の組名合わせによるユニークな現象として注目を集め ている.

噴霧熱分解法を用いて $\mathrm{TiO}_{2}-\mathrm{Ag}$ ナノ複合粒子在生成し, 3D-ETを用い， $\mathrm{Ag}$ 粒子がどの様に $\mathrm{TiO}_{2}$ 母相中に分散して いるかを観察した。

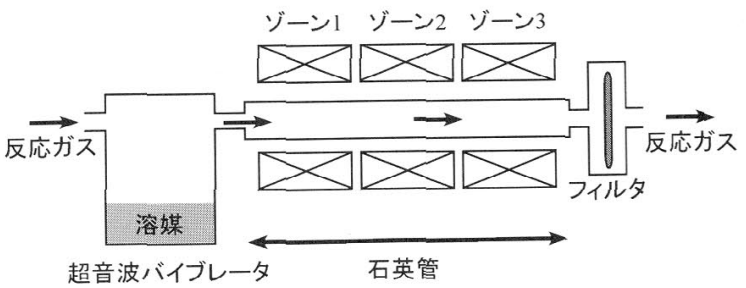

図14 噴霧熱分解法の概略図 ${ }^{(36)}$.

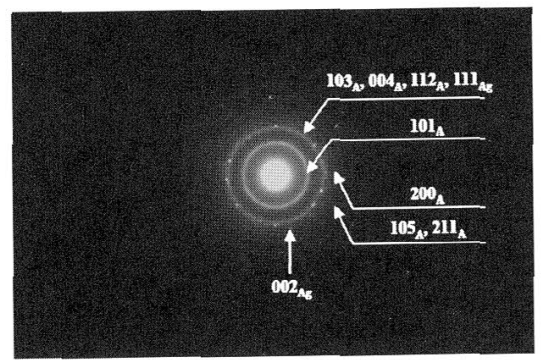

\begin{tabular}{|l|c|c|}
\hline & 面指数 & 組成 \\
\hline$d_{1}$ & 101 & アナターゼ \\
\hline$d_{2}$ & 103 & アナターゼ \\
& 004 & アナターゼ \\
& 112 & アナターゼ \\
& 111 & 悢 \\
\hline$d_{3}$ & 002 & 銀 \\
\hline$d_{4}$ & 200 & アナターゼ \\
\hline$d_{5}$ & 105 & アナターゼ \\
& 211 & アナターゼ \\
\hline
\end{tabular}

図15 制限視野回折法により生成された複合粒子の組 成は銀とアナターゼからなることが判る。

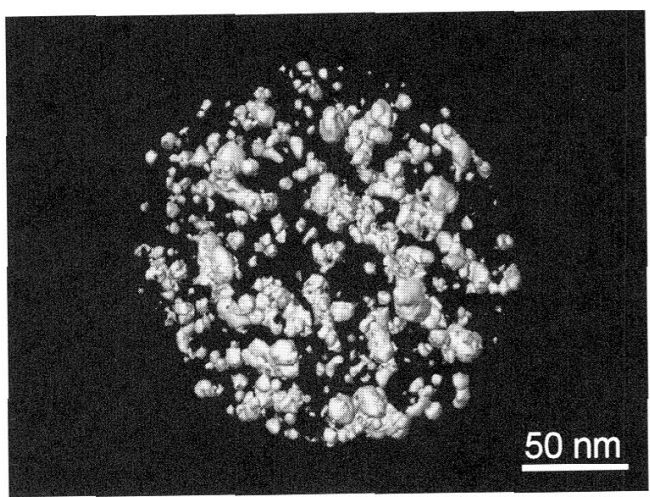

図16 3D-ET 法による観察結果から複合粒子中に銀が 分散している様子が伺える。 
噴霧熱分解法(図14) (36)を用いて $\mathrm{TiO}_{2}$ ゾルと硝酸銀を高温 炉内に噴霧し, 瞬時に熱分解, 反応が拈き, $\mathrm{TiO}_{2}-\mathrm{Ag}$ ナノ 複合粒子の合成を行った。

噴霧熱分解法を用いた試料から，3D-ET法により，微細 な銀粒子がナノ複合粒子中に分散し，アナターゼと複合粒子 を形成していることが判明した(図15，図16).

通常, TEM 用の薄膜試料を作製する場合, 機械研磨やミ クロトームによる試料切断等, 応力がかかり本来の試料形態 を観察していないのではという危惧もあったが，3D-ET 法 により, 非破壊的に複合粒子の三次元ナノ形態観察・解析が 可能であることを示した例である.

\section{5. を め}

本稿では 3D-ET 法の原理と現状，および応用例について 紹介した. 特に材料学的に興味深い試料の3D-ETを行うこ とにより, 従来の二次元像から得ることが不可能で女った深 さ・厚み方向の情報や材料, 析出物の形態・分散状態等, を 論ずることが可能となった。3D-ET が普及しつつあり，今 後コンピュータの性能向上に伴って更なる発展が期待され る. 今回紹介した析出物や触媒などに抢ける貴金属粒子の分 散状態など様々な応用分野が考えられる。

\section{文献}

(1) K. Hono: Acta Materialia, 7(1999), 3127-3145.

(2) D. Scott, F. Duewer, S. Kamath, A. Lyon, D. Trapp, S. Wang and W. Yun: Proc. LSI Testing Symposium, (2005), 195-200.

( 3 ) S. H. Ferris, M. J. de Leon, A. P Wolf, T. Farkas, D. R. Christman, B. Reisberg, J. S. Fowler, R. Macgregor, A. Goldman, A. E. George and S. Rampal: Neurobiology of Aging, 1(1980), 127-131.

(4) G. Mobus, R. C. Doole and B. J. Inkson: Ultramicroscopy, $\mathbf{9 6}$ (2003), 433-451.

(5) K. Kimura, S. Hata, S. Matsumura and T. Horiuchi: J. Electron Microscopy, 54(4) (2005), 373-377.

(6) K. Kaneko, W. J. Moon, K. Inoke, Z. Horita, S. Ohara, T. Adschiri, H. Abe and M. Naito: Mater. Sci. and Eng., A 403(12): (2005), 32-36.

(7) A. M. Cormack: J. of Appl. Phys., 34 (1963), 2722-2727.

(8) J. Radon: Math.-Phys., 69(1917), 262-267; English translation in S. R. Deans, The Radon transform and some of its applications: John Wiley, (1983), 204-217.

(9) G. H. Hounsfield: British J. Radiology, 46 (1972), 1016-1022.

(10) J. P. Heiken, J. A. Brink and M. W. Vannier: Radiology, $\mathbf{1 8 9}(\mathbf{3})(1993), 647-656$.

(11) H. E. Martz, G. P. Roberson, M. F. Skeate, D. J. Schneberk and S. G. Azevedo: Nuclear Instruments and Methods in Physics Research, B58 (1991), 216-226.

(12) A. Klug and D. J. DeRosier: Nature, 212 (57) (1966), 29-32.

(13) R. McIntosh, D. Nicastro and D. Mastronarde: TRENDS in Cell Biology, 15 (2005), 43-51.

(14) A. J. Koster, A. Vandenbos and K. D. van der Mast: Ultramicroscopy, 21(1987), 209-222.

(15) P. A. Midgley, M. Weyland, J. M. Thomas and B. F. G. Johnson: Chem. Commun., (2001), 907-908.

(16) J. Liu and J. M. Cowley: Ultramicroscopy, 37 (1991), 50-71.

(17) J. N. Turner and U. Valdrè: Ed. By J. Frank: Electron tomography, Plenum press, $185-191$.

(18) B. K. Rath, M. Marko, M. Radermacher and J. Frank: J. Struct. Biol., 120 (1997), 210-218.

(19) B. F. McEwen, K. H. Downing and R. M. Glaeser: Ultramicroscopy, 60(1995), 357-373.

(20) R. Marabini, E. Rietzel, R. Schroeder, G. T. Herman and J. M. Carazo: J. of Struct. Biol., 120(1997), 363-371.

(21) A. H. Andersen and A. C. Kak: Ultrason. Img., 6 (1984), 8194.

(22) R. Gordon, R. Bender and G. T. Herman: J. Theoretical Biology, 29 (1970), 471-481.

(23) R. H. M. Schoenmakers, R. A. Perquin, T. F. Fliervoet and W Voorhout: Microscopy and Microanalysis, 11, Supplement S02, 8(2005), 312-313.

(24) V. Lucic, F. Forster and W. Baumeister: Annu. Rev. Biochem., 74(2005), 833-865.

(25) D. N. Mastronarde: J. Struct. Biol., 120(1997), 343-352.

(26) J. Tong, I. Arslan and P. Midgley: J. Struct. Biol., 153(2006), 55-63.

(27) P. Penczek, M. Marko, K. Buttle and J. Frank: Ultramicroscopy, 60(1995), 393-410.

（28）矢口紀恵：セラミックス，40(2005)，932-936.

(29) P. A. Midgley and M. Weyland: Ultramicroscopy 96 (2003), 413-431.

(30) K. Inoke, K. Kaneko, M. Weyland, P. A. Midgley, K. Higashida and Z. Horita: Acta Materialia, Accepted.

(31) R. B. Nicholson and J. Nutting: Acta Metallurgica, 9(1961), 332-343.

(32) A. Kelly and R. B. Nicholson: Prog. Mater. Sci., 10(1963), 151.

(33) Z. Horita, K. Ohashi, T. Fujita, K. Kaneko and T. G. Langdon: Advanced Materials, 17(2005), 1599-1602.

(34) K. Kaneko, R. Nagayama, K. Inoke, E. Noguchi and Z. Horita: Adv. Sci. Tech., Submitted.

(35) Y. Ohko, T. Tatsuma, T. Fujii, K. Naoi, C. Niwa, Y. Kubota and A. Fujishima: Nature Materials, 2(2003), 29.

(36) T. Fukui, T. Oobuchi, Y. Ikuhara, S. Ohara and K. Kodera: J. American Ceramics Society, 80 (1997), 261-263.

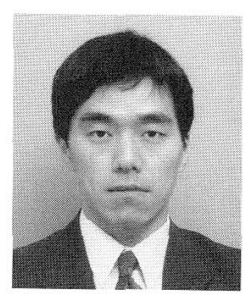

伊野家浩司

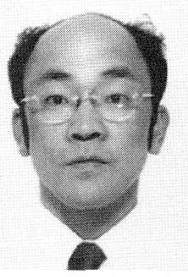

金子賢治

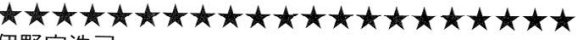 伊野家浩司}

1996年 東京農工大学工学研究科修士課程修了

1996年 日本フィリップス(現フィリップス・エレク トロニクス・ジャパソ)入社

2000年 現職

専門分野：透過型電子顕微鏡

透過型電子顕微鏡を用いた評価技術の開発・応用に従 事.
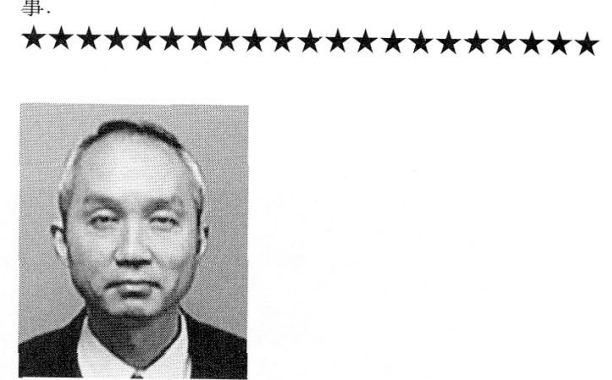

堀田善治 